UDC 629.3.014.7+629.3.022.4

L. Petrov ${ }^{1}, \mathrm{PhD}$, Assoc. Prof.,

T. Borisenko',

I. Kishianus ${ }^{1}$,

Y. Petrik ${ }^{1}$

${ }^{1}$ Military Academy (Odessa), 10 Fontanska doroga Str., Odessa, Ukraine, 65009; e-mail: leonid.petrov2@gmail.com

${ }^{2}$ LLC “TELECARD-PRILAD”, 105 Nebesnoi Sotni Ave., Odessa, Ukraine, 65104; e-mail: borisenko.taras@gmail.com

\title{
THEORETICAL ELEMENTS OF ENERGY MODULAR LAYOUT OF AUTOMOBILE SYSTEM
}

Л.М. Петров, Т.М. Борисенко, І.В. Кішянус, Ю.М. Петрик. Теоретичні елементи енергомодульної компоновки автомобільної системи. В статті приведена фізико-математична модель енергомодульної компоновки транспортного засобу. Розглянута методика моделювання руху автомобільної системи з головними зв'язками на основі рівнянь Лагранжа. При проектуванні автомобільної системи запропоновано дослідження і обгрунтування взаємодії рухомих платформ у складі безпосередньої автомобільної системи. Така автомобільна система тісно пов'язана з механічною та технологічною її підсистемами, які використовуються в роботі шляхом їх взаємодії. Для опису автомобільної системи використовуємо математичні залежності, які узгоджують безпосередньо параметри, які впливають на виконавчі органи автомобільної системи. Такий підхід дозволяє представити модель автомобільної системи як сукупність двох платформ , силових факторів та механічних зв'язків, що забезпечує їх поєднання в одному робочому процесі. Складено рівняння та проведені розрахунки для змінення кінетичної енергії при різних режимах руху автомобільної системи. Метою дослідження є удосконалення технології переміщення автомобільної системи з-за використання в ній сукупності двох рухливих платформ. Наукова та практична значущості роботи полягає в тому, що вперше запропонована технологія в якій для переміщення автомобільної системи використана енергія взаємодії двох платформ. Методологією дослідження являлося встановити математичний зв'язок узагальненої сили з динамікою взаємодії платформ, які відповідають за рух автомобільної системи. Результатом є розроблена геометрія роботи взаємодії платформ у циклі демпфування взаємодіючих платформ. Цінність проведеного дослідження, результати проведеної роботи дозволять зробити внесок в галузь автомобільного виробництва. Запропоновано модель для зниження енергії на створення руху транспортного засобу.

Ключові слова: фізико-математична модель, рушій, колесо, автомобільна система, платформа

L. Petrov, T. Borisenko, I. Kishianus., Y. Petrik. Theoretical elements of energy modular layout of automobile system. The article presents a physical and mathematical model of the energy-modular configuration of a vehicle. A technique for modeling the motion of an automobile system with main connections based on the Lagrange equations is considered. This approach allows us to represent the model of the automotive system as a combination of two platforms, force factors and mechanical links, ensures their combination in one workflow. An equation has been drawn up and calculations have been carried out to change the kinetic energy for various modes of motion of the automobile system. The aim of the study is to improve the technology of moving the automotive system using a combination of two mobile platforms. The scientific and practical significance of the work lies in the fact that for the first time a technology has been proposed in which the energy of interaction of two platforms is used to move the automobile system. The research methodology was to establish a mathematical relationship between the generalized force and the dynamics of platform interaction, which is responsible for the movement of the automotive system. The result is the developed geometry of the interaction between platforms in the damping cycle of the interacting platforms. The value of the study, the results of the work carried out make it possible to contribute to the automotive industry. A model is proposed to reduce the energy to create vehicle motion.

Keywords: physical-mathematical model, mover, wheel, car system, platform

\section{Introduction}

Cars are an important tool for improving Ukraine's economy. In the current period of development of the economies of the world, the further development of economic sectors is closely linked with the latest technologies for the development of transport. Reliable operation of cars with low operating costs ensures the implementation of the technological rhythm of such sectors of the economy as industry, construction, agriculture, etc.

Cars are included in the complex transport system of Ukraine. Such a transport system includes interaction with other modes of transport. Moreover, cars are included in the chain of delivery of goods or in the chain of interaction with other modes of transport.

Freight transported by car increases in volume much more than cargo transported by other modes of transport.

\section{DOI: 10.15276/opu.1.63.2021.02}

(C) 2021 The Authors. This is an open access article under the CC BY license (http://creativecommons.org/licenses/by/4.0/). 
Increased intensity of car operation and their disproportionately high growth is accompanied by adverse effects on the environment. For example, maintenance of the destroyed road surface and the release of the gas component from the friction of tires on a hard surface and the formation of dust.

Developed countries of the world produce cars that seem to meet modern requirements. But the operating conditions of cars are very complex and diverse and it is impossible to carry out all design improvements to the ideal.

Given the experience of economically developed countries in the design of cars, it is possible to say with some probability that the design of cars in Ukraine will be associated with the use of developments of advanced automotive countries. Given this experience, we propose to consider the car in terms of the dynamics of the material system.

One of the difficulties in solving problems of dynamics of material systems (automotive systems) with two degrees of freedom is the choice of the general theorem of dynamics. In the proposed automotive system with several degrees of freedom to solve problems performed using military vehicles, are much more complicated, as it requires the joint application of several general theorems and equations of dynamics.

For the proposed automotive system, it is most convenient to use the Lagrange equation of the second kind. They are a universal method of compiling differential equations of motion of material systems (automotive systems). Due to this generalization, the Lagrange equation is widely used to solve a variety of technical problems [1].

\section{Analysis of recent publications and problem statement}

A large number of authors dealt with the question of the dynamics of the calculation of a complex mechanical system. Extensive experience in studying the dynamics has accumulated in the developers involved in the dynamics of overhead cranes. From this experience, as a basis we take multiweight dynamic models, which consist of concentrated masses connected between them by elasticviscous bonds [2, 3]. Authors Galdinim N.S., Kurbatskaya S.V., Kurbatskaya O.V. [4]. the analysis of scientific works of Ananin V.G., Kalinichenko V.S., [5, 6, 7] which investigated dynamics of loadlifting machines is carried out. According to these studies, the motion of such models of machines in transient modes, which are described by systems of differential equations, was taken as a basis. Based on their solutions (taking into account the assumptions made) it is possible to formulate conclusions about the quality of the proposed model.

Fig. 1 shows a three-mass dynamic model of a overhead crane.

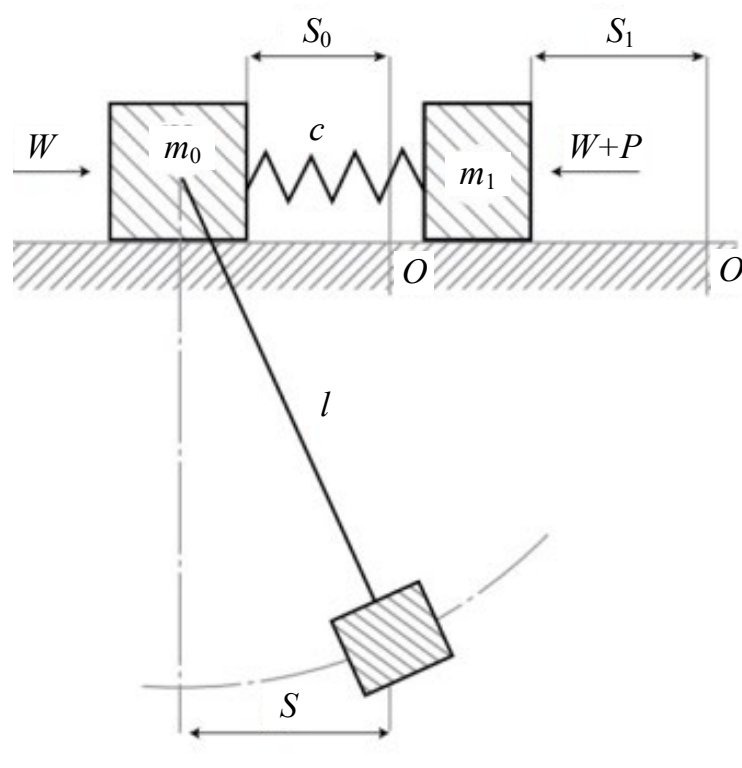

$a$

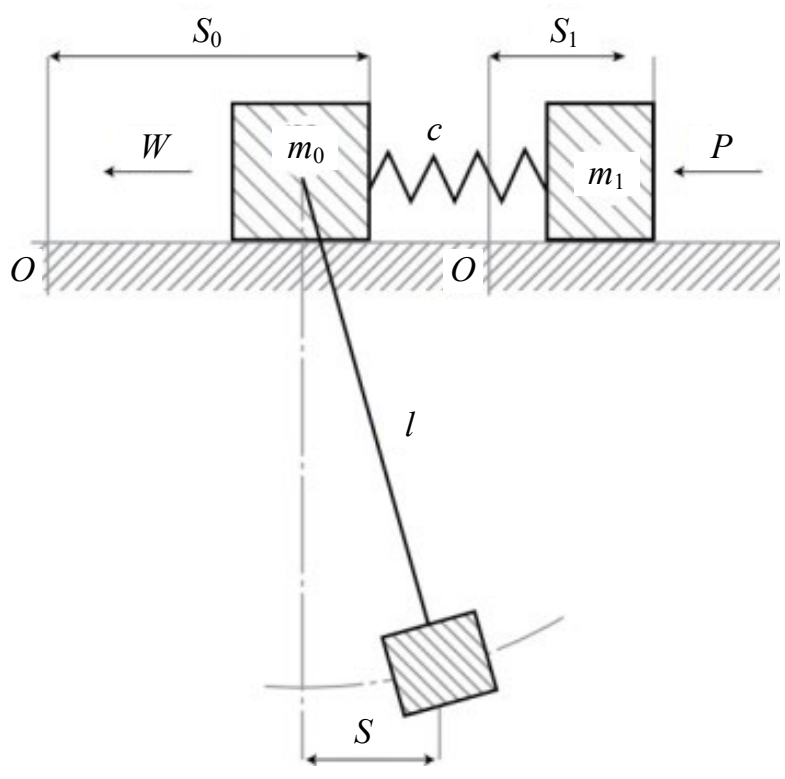

$b$

Fig. 1. Three-mass dynamic model of the overhead crane: at start-up $(a)$; when braking $(b)$ 
In his work, Zhegulsky V.P. considered dynamic loads in elastic elements of the mechanism of movement of metalwork of the crane taking into account elastic pliability. In this approach, the author investigated a two-mass single-connected dynamic model of Fig. 2.

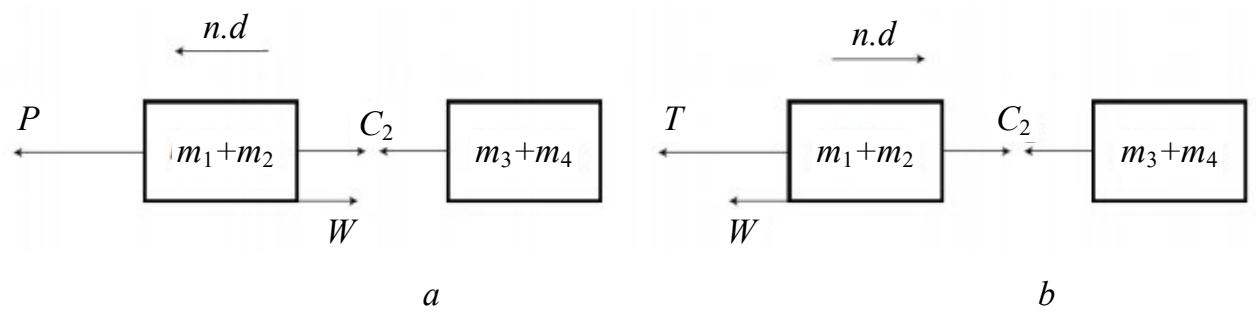

Fig. 2. Single-connected dynamic model of the overhead crane: acceleration $(a)$; braking $(b)$

In [8], a three-mass two-connected dynamic model was used to determine inertial loads, Fig. 3.

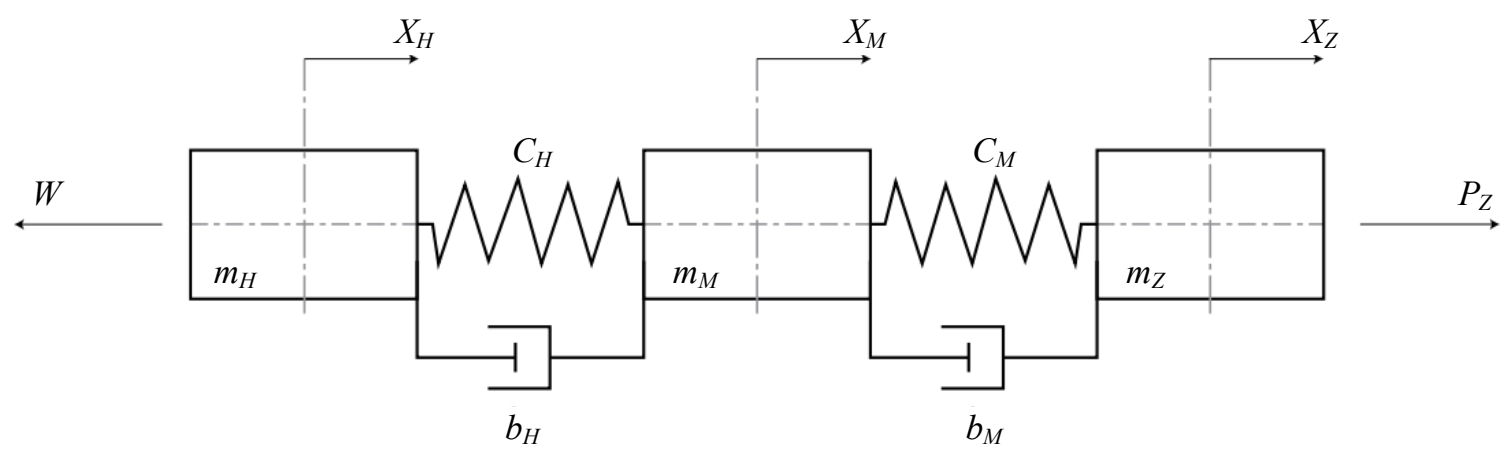

Fig. 3. Three-mass two-link dynamic overhead crane model

The method of Lagrange equations of the second kind was used to compile the equations of motion of the dynamic calculation scheme. It is used to solve a wide range of dynamics problems and allows obtain numerical algorithms for modeling the motion of complex systems [9]:

$$
\frac{d}{d t}\left(\frac{\partial K}{\partial g_{j}}\right)-\frac{\partial K}{\partial g_{j}}+\frac{\partial P}{\partial g_{j}}+\frac{\partial F}{\partial g_{j}}=F_{j}(j=1,2 \ldots l),
$$

where $K$ - kinetic energy of the system; $P$ - potential energy of the system; $F$ - dissipative function; $t$ - hour; $g_{j}-j$-a generalized coordinate of movement; $g_{j}$ - generalized speed coordinate; $F_{j}$ - generalized force acting on the $j$-th generalized coordinate.

Technological machines and complexes and automotive systems are characterized by wide functionality, complexity and variety of means of assembling assemblies and units on the basis of which they are created, increased duration of their development, long experimental research, construction of their models, assemblies and units.

In the design of the automotive system, research and substantiation of the interaction of mobile platforms in the direct automotive system are proposed. Such an automotive system is closely related to its mechanical and technological subsystems, which are used in the work through their interaction. To describe the automotive system, we use mathematical dependencies that directly coordinate the parameters that affect the executive bodies of the automotive system.

When developing an automotive system with new technological capabilities that do not exist in world practice, we consider it as a single system from the standpoint of solving problems in theoretical mechanics with certain limitations.

For example, in [10] to clarify the force dependences (Fig. 4), a simplified static model of the mechanism was presented. The axial force $P_{0}$, which develops the rod of the hydraulic cylinder 1 , 
causes the axial movement of the camshaft 2 , which carries two helical gears 3 and 4 . The latter are coupled to the teeth of two helical gears 5 and 6 , which are fixed to the shafts of the rack gears 7 and 8 . with the teeth of the rail 9 . With a fixed drive gear 10 , the axial movement of the camshaft 2 causes mutually opposite angular movements of the rack gears with simultaneous force elimination of gaps in all elements in contact in the closed kinematics of the circuit.

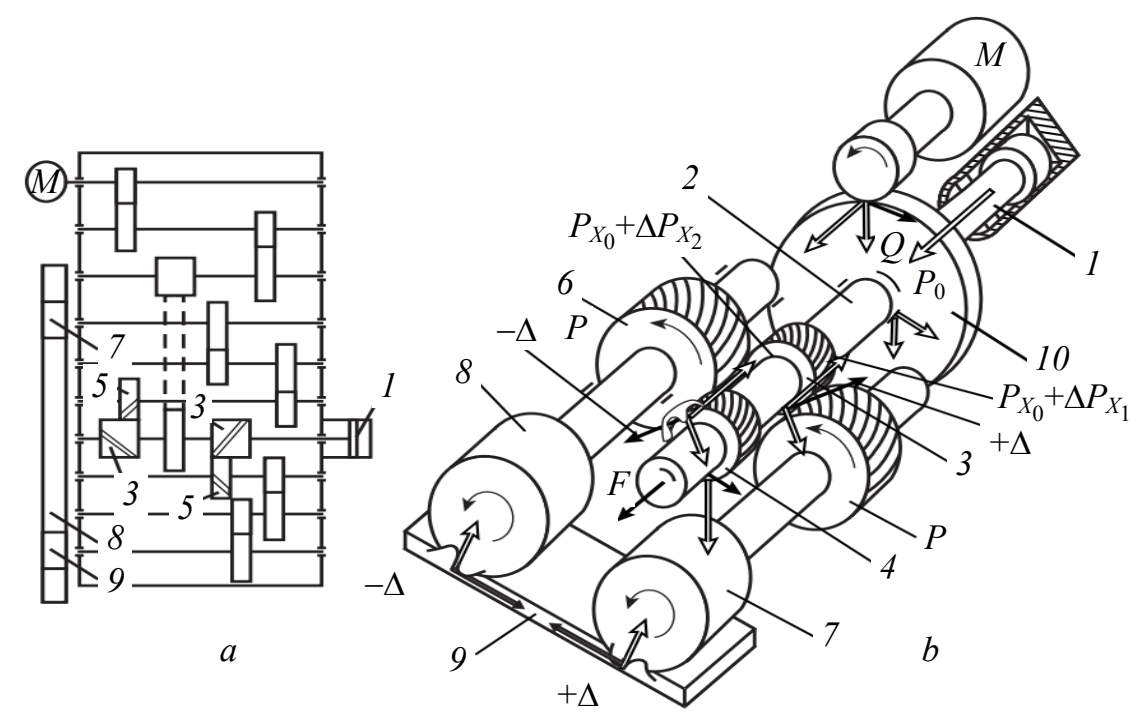

Fig. 4. Closed drive mechanism: kinematic scheme (a); power dependencies $(b)$

Replacement of the distributed moment of inertia of the screw by the moments of inertia concentrated on the ends is carried out according to Fig. 5.

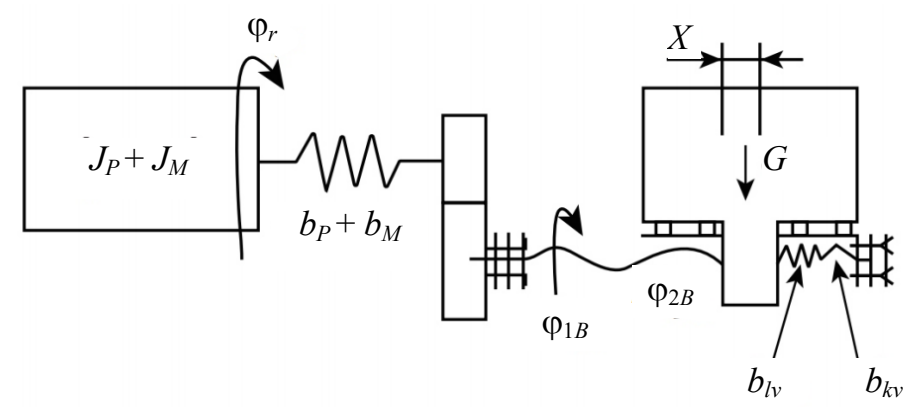

Fig. 5. Calculation scheme for determining the personal oscillation frequencies of the drive mechanism: $J_{P}, J_{M}$ - moment of inertia, respectively, of the motor rotor and clutch, as well as the moment of inertia of the gearbox reduced to the clutch; $G$ - weight, moving parts; $b_{M}, b_{P}$ - angular compliance, respectively, the clutch and the gearbox, which is reduced to the shaft of the clutch; $b_{l, v}, b_{k, v}$ - linear and torsional flexibility of the screw; $\varphi_{1 B}, \varphi_{2 B}$ - angles of rotation of the ball screw at the input gear and the nuts, respectively; $\varphi_{r}-$ angle of rotation of the motor rotor; $X$ is the linear movement of the carriage

The mechanical part of the conveyors is a system with parameters distributed along the length of the conveyor: the weight of the moved load, the weight and elasticity of the traction body, the force of static resistance. The presence of elastic mechanical connections contributes to the occurrence of oscillations, which under adverse conditions significantly increase the dynamic loads of the equipment. The motion of a system with distributed parameters is described by differential equations in isosceles.

To consider the physical processes that occur in the starting modes of conveyors, the authors Rogovenko T.M., Zaitseva M.M. proposed a simplified dynamic model in which the distributed 
weights and forces of elasticity and force are replaced by equivalent concentrated parameters. To compile the model, the authors proposed a diagram of the tension of the traction body of the conveyor in the start-up mode. In this work, under the condition of equivalence, the equality of the tension of the traction body on the drive element of the real system is assumed to be equilibrium at the corresponding points of the drive element on the model.

The dynamic model of the moving part of the conveyor has the form (Fig. 6, $a$ ), and its calculation scheme, which is reduced to a gradual movement - (Fig. 6, $b$ ).
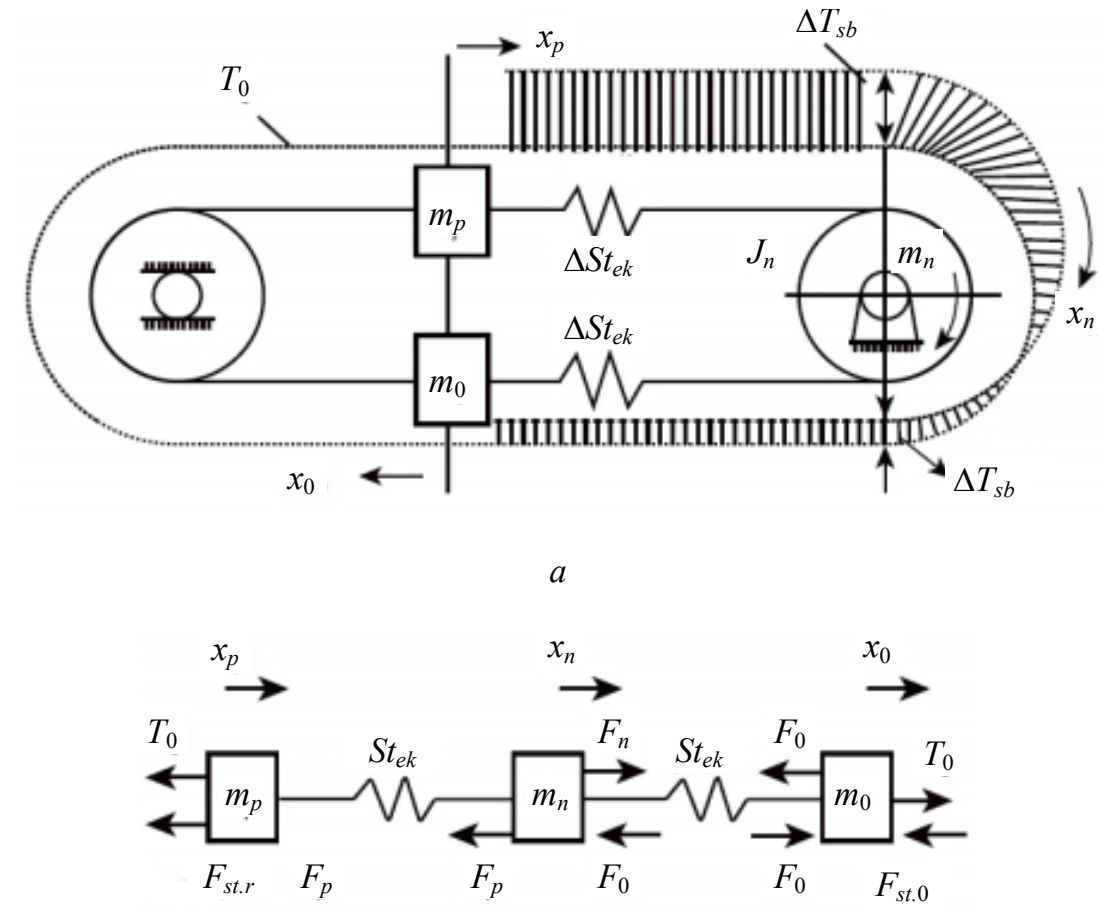

$b$

Fig. 6. Dynamic model of the moving part of the conveyor $(a)$ and the calculation scheme, which is reduced to a gradual movement $(b)$

The following notations are accepted: $m_{p}, m_{0}$ - the resulting weights of the working and idle branches of the conveyor, respectively, taking into account the reduced weight of the tension drum; $m_{n}=\frac{J_{n}+J_{d v} \cdot i_{p 2}}{R_{n 2}}-$ the weight of the drive, which is reduced to a gradual movement; $S t_{e k}$ - equivalent stiffness of the branches of the traction body; $x_{n}, x_{p}, x_{0}$ - coordinates of concentrated weights, respectively, $m_{n}, m_{p}, m_{0} ; F_{p}=S t_{e k}\left(x_{n}-x_{p}\right)$ and $F_{0}=S t_{e k}\left(x_{n}-x_{0}\right)$ - respectively, the elastic forces of the working and idle branches of the traction body; $F_{\text {st. }}, F_{\text {st. } 0}$ - respectively, the resulting efforts of static resistance of the working and idle branches of the traction body, and $F_{s t . r}+\mathrm{F}_{s t .0}=F_{s t} ; \quad F_{n}=m_{n} \cdot \frac{i_{p}}{R_{n}}$. The motion of the drive according to the obtained dynamic model is described by a system of differential equations, which does not take into account damping.

Figures 7,8 show the functional diagrams of the most common bridge and gantry cranes. 


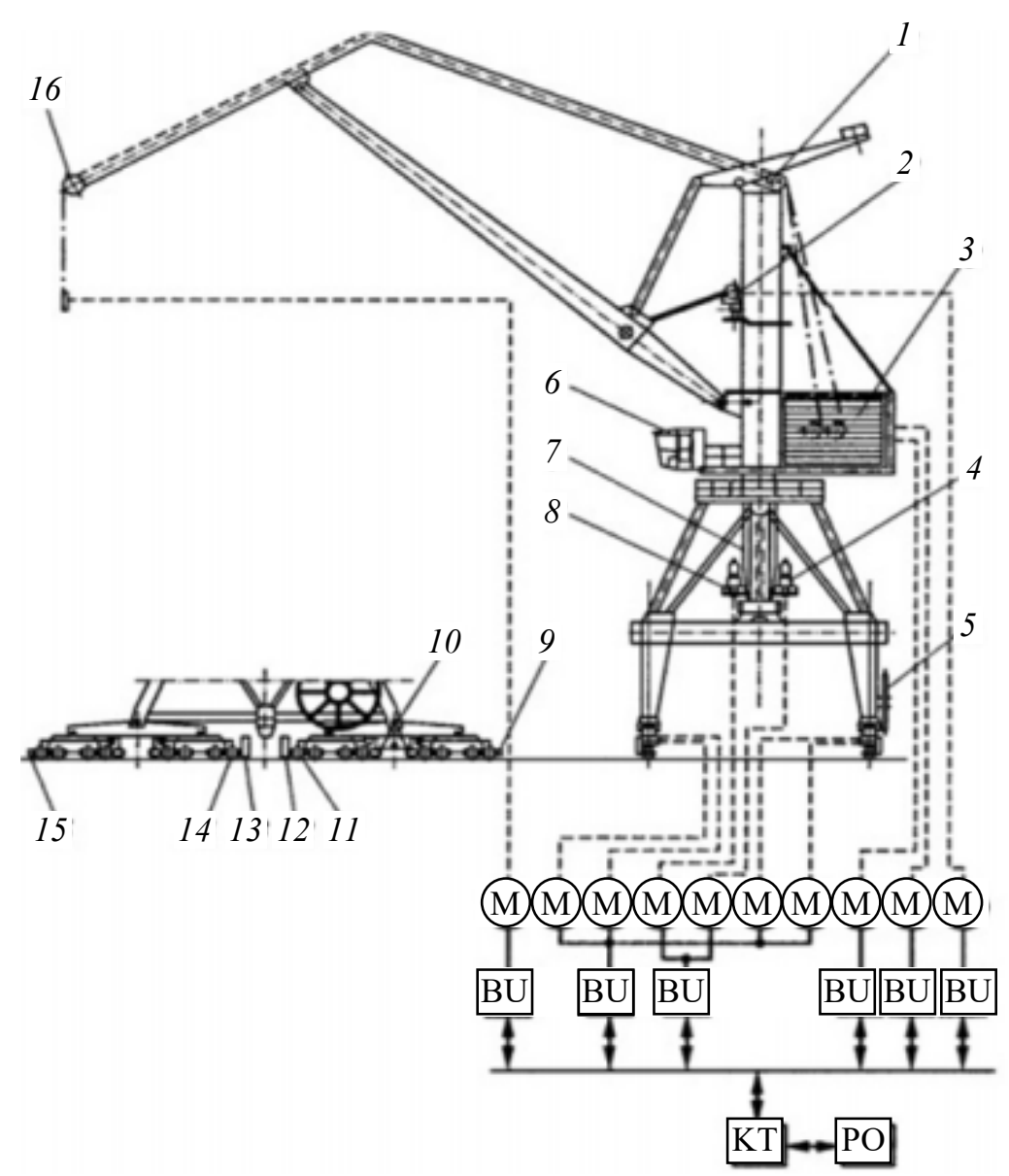

Fig. 7. Schematic representation of the portal crane

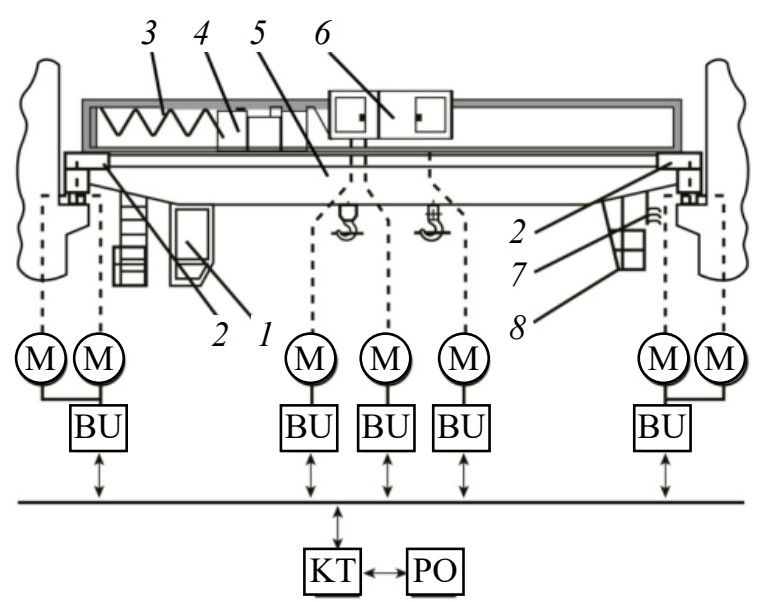

Fig. 8. Functional diagrams of overhead and portal cranes

The problems of automatic load balancing of axle and platform drives and control of cargo movement with prevention of its unrolling are solved [11].

Crane movement control system to prevent unrolling of cargo. Let's perform a mathematical description and investigate the dynamic processes on the example of the control system of the bridge crane. Fig. 9, $a$ represents a mechanical system of trolley-suspension-load. 
In Fig. 9 the authors Rogovenka T.M., Zaitseva M.M. took the following notation: $m_{1}-$ weight of the cart; $m_{2}$ - weight of cargo; $l$ is the length of the suspension; $F$ is the force applied to the cart; $\varphi-$ angle of deviation of the load from the equilibrium position. We assume that the suspension is a weightless equilibrium thread, the weight $m_{1}$ is concentrated in the center of the weight of the cart, and the weight $m_{2}-$ at the point of attachment of the load to the suspension.

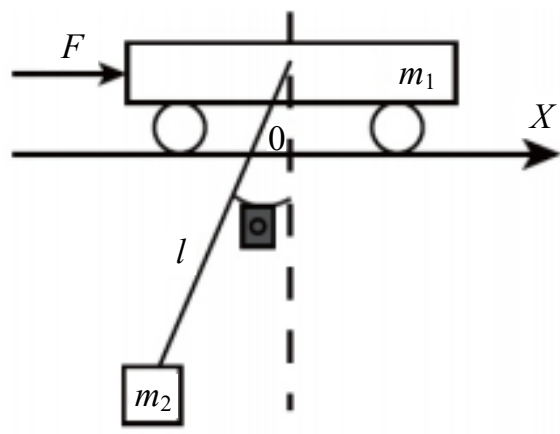

$a$

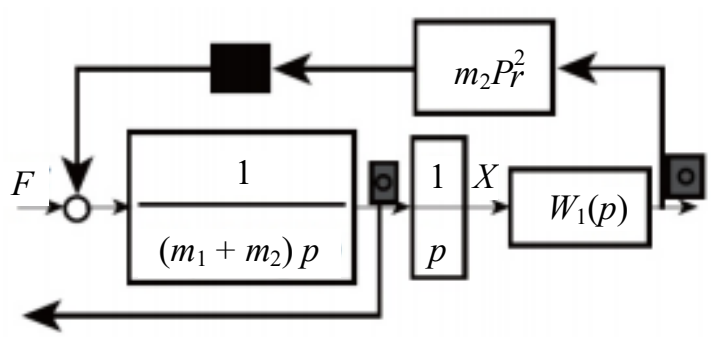

$b$

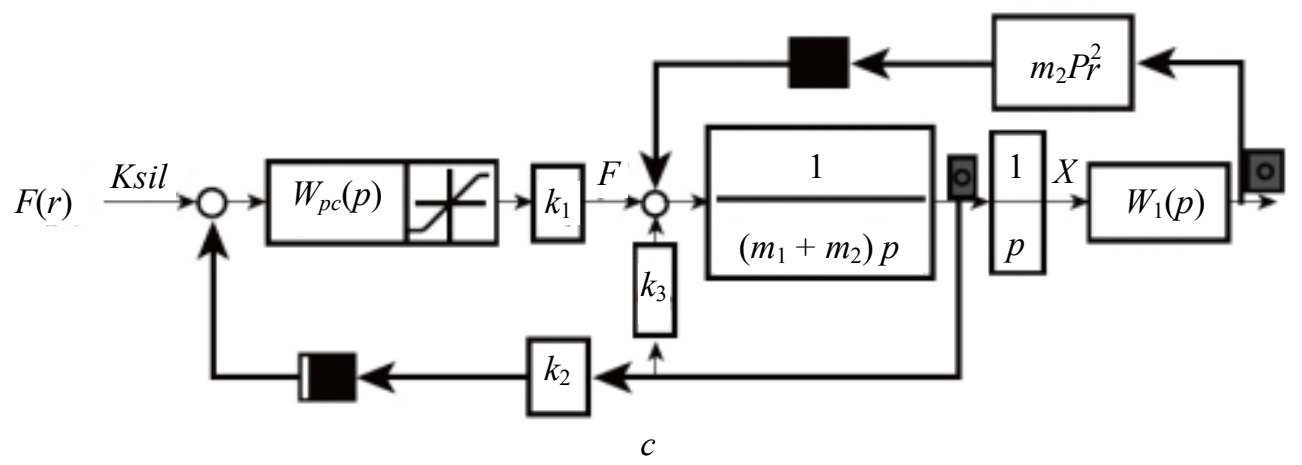

Fig. 9. Scheme of the mechanical system of trolley-suspension-load: $a$ and $b$ structural diagrams of the mechanical system and the closed control system taking into account the action of friction forces $(c)$

The Lagrange equation was compiled for the proposed mechanical system "trolley-suspensionload". In the general case for the $i$-th degree of freedom of the Lagrange equation, taking into account the kinetic and potential energy, the author [4] reduces equation to the form (1):

$$
\frac{d}{d t}\left(\frac{\partial L}{\partial g_{i}}\right)-\frac{\partial L}{\partial g_{i}}=Q_{i}
$$

where $L=T-P$ is the Lagrange function; $T, P$ - the total reserve of kinetic and potential energy of the system, respectively ; $Q_{i}$ - generalized non-conservative forces; $g_{i}$ - generalized coordinates and velocities.

The variables $x$ and $\varphi$ are also accepted as generalized coordinates.

The kinetic and potential energies of the system were determined by the formulas:

$$
\begin{gathered}
T=m_{1}+m_{2} \frac{x^{2}}{2}+m_{2} l x \varphi \cos \varphi+J \frac{\varphi^{2}}{2} ; \\
P=-m_{2} g l \cos \varphi,
\end{gathered}
$$

where $J=l^{2} \cdot m_{2}-$ moment of inertia of the load.

Thus, the Lagrange function for this system of trolley-suspension-load is written as: 


$$
L=T-P=m_{1}+m_{2} \frac{x^{2}}{2}+m_{2} l x \varphi \cos \varphi+J_{g r} \frac{\varphi^{2}}{2}+m_{2} g l \cos \varphi .
$$

The generalized forces corresponding to the accepted generalized coordinates will look like:

$$
\begin{gathered}
Q_{x}=F, \\
Q_{\varphi}=0 .
\end{gathered}
$$

The obtained mathematical dependences (2), (3) and (4) are substituted into Lagrange's equation (1) and differentiation is performed. Due to this technique, the equations of motion were obtained:

$$
\begin{gathered}
\frac{d}{d t}\left(\frac{\partial l}{\partial x_{i}}\right)-\frac{\partial L}{\partial x_{i}}=\left(m_{1}+m_{2}\right) x+m_{2} l_{\varphi} \cos \varphi-m_{2} l \dot{\varphi}^{2} \sin \varphi=F, \\
\frac{d}{d t}\left(\frac{\partial l}{\partial \varphi_{i}}\right)-\frac{\partial L}{\partial \varphi_{i}}=m_{2} l x \cos \varphi+m_{2} l^{2} \dot{\varphi}+m_{2} g l \sin \varphi=0, \\
\left(m_{1}+m_{2}\right) p^{2} x+m_{2} l p^{2} \dot{\varphi}=F .
\end{gathered}
$$

Taking into account the changes made in (7), the block diagram of the linear velocity of the trolley takes the form presented in (Fig. 9, $c$ ), where the following notation:

$-F(r)$ - the function of forming the problem of the speed of the cart;

$-x_{z a d}$ - set value of the trolley speed;

$-W_{p c}$ - transfer function of the speed regulator;

- link that reflects the electromagnetic processes of the drive motor and serves to bring the electromagnetic torque of the motor to a linear force acting on the cart;

$-k_{2}$ is the negative feedback rate.

Mathematical modeling of complex technical systems is purposeful when the technical system can be divided into several interconnected components, each of which is in the technical system.

For construction and manipulation equipment, the division into a subsystem that describes the movement of system elements and a hydraulic-pneumatic drive subsystem describing the occurrence of forces between system elements is common. This approach simplifies both the creation and analysis of mathematical models.

\section{The purpose and objectives of research}

The purpose of the study is to improve the technology of moving the automotive system using a set of two mobile platforms.

There are three main tasks of modeling the movement of machines:

1. Newton-Euler equations, which allow to obtain a description of the dynamics of the machine. The centrifugal and Coriolis forces are not taken into account. This affects the accuracy of calculations and is not convenient to use for complex technical processes.

2. Generalized equations of D. Alambert. This is a difficult path, there are difficulties in its application, but shows the full picture of the dynamics of the machine.

3. Using the Lagrange-Ehler equations. Such equations reflect the full picture of the dynamics of the machine and are easy to analyze.

\section{Presentation of the main material (Materials and methods of research)}

In our work, the Lagrange equations of the coordinates of the motion of the automotive system were used, taking into account the following assumptions.

The car system is a hinged spatial, multi-chain design.

The structural elements of the automotive system are presented as absolutely rigid rods.

Each structural element of the automotive system is provided with its own local coordinate system.

The joints in the hinges are holonomic (a mechanical connection that imposes restrictions only on the position or movement of points and bodies of the automotive system) and stationary. 
Mathematically, this relationship will be represented as an equation:

$$
f_{i}\left(g_{1}, g_{2}, \ldots, g_{i}\right)=0 \text {, }
$$

where $g_{i}$ - generalized coordinates that describe the mechanical system; $i=1 \ldots k, k-$ the number of holonomics superimposed.

We assume that the backlash and dry friction forces in the hinges are absent.

The whole physical and mathematical model of the automobile system, Fig. 10, was divided into two parts: the technological platform and the cargo platform.

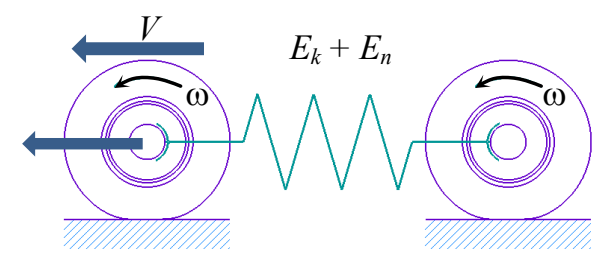

Fig. 10. Physical and mathematical model of the automobile system

Based on this, we made a drawing of the relationships between the subsystems (technological platform and loading platform), which is shown in (Fig. 11, 12, 13) [10, 12].

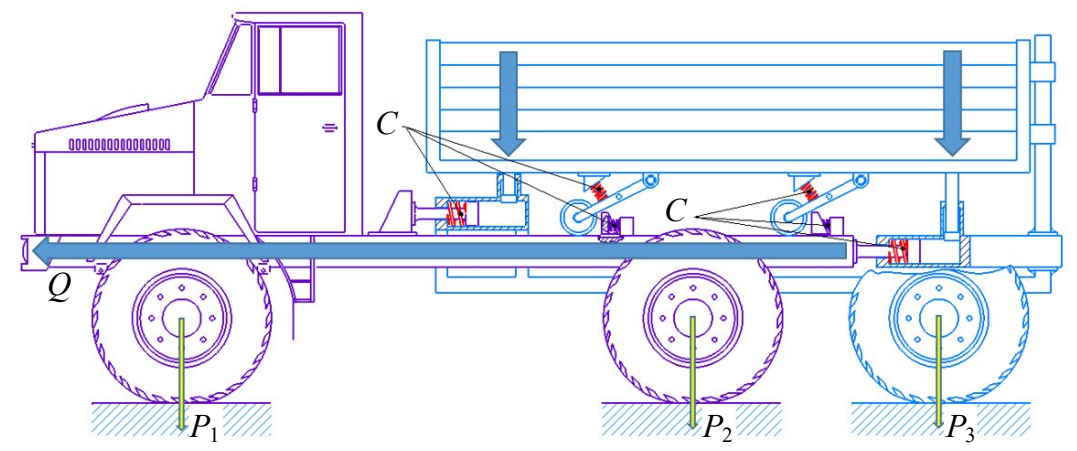

Fig. 11. Forces acting between the subsystems of the automotive system (static position)

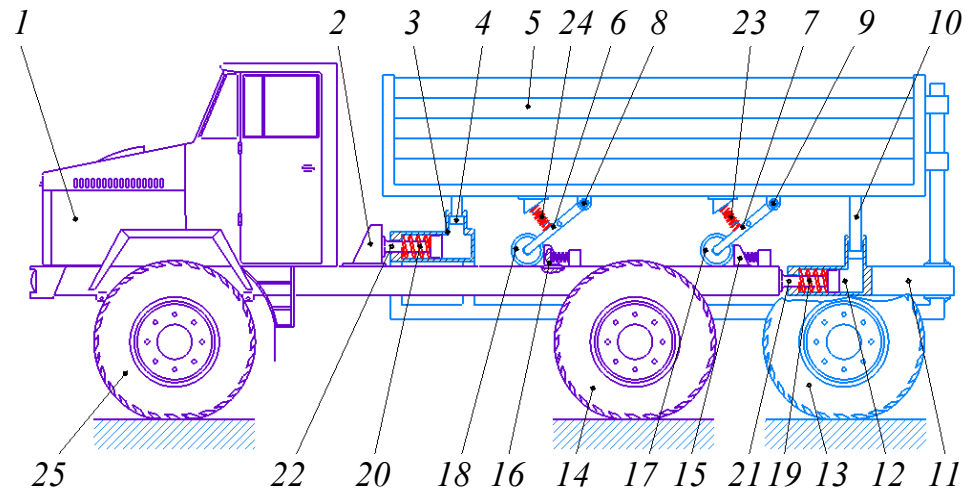

Fig. 12. Scheme of the car system in a static position: 1 - engine; 2,3 - driven wheels; 4,5 - stops; 6 - stop bracket; 7 - wheel; 8 - cargo platform; 9, 10 - mobile wheels; 11, 12 - openings; 13, 14 - levers; 15, 16hinges; 17 - stretcher; 18 -drive; 19, 20,22, 23 - piston with rod; 21 - damper 


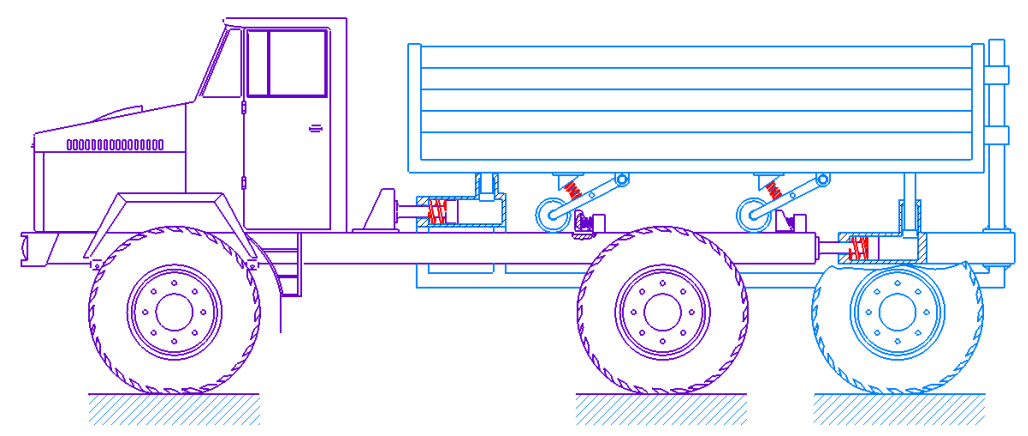

Fig. 13. Scheme of the car system in a dynamic position (the movement of the car system)

The automotive system consists of two platforms: the technology platform and the loading platform.

This system has two degrees of freedom. We choose as a generalized coordinate the angle $\varphi$ of rotation of the wheel 1 from 12 and the equilibrium position (at equilibrium $\varphi=0, S_{A}=0$ and $S_{3}=0$ ). At the beginning of the motion of the automobile system, we consider small oscillations, given that the angle $\varphi$ is small (Fig. 1, $b$ ).

Since all the active forces acting on the system are potential (gravity and elastic force), we express the generalized force $Q_{\varphi}$ through the potential energy $P$ of the system. The motion of this mechanical system is written by one Lagrange equation of the second kind:

$$
\frac{d}{d t}\left(\frac{\partial T}{\partial \varphi}\right)-\frac{\partial T}{\partial \varphi}=Q_{\varphi}
$$

The potential energy of the system is defined as the sum of the potential energy $P_{1}$, which corresponds to the forces of elasticity, and the potential energy $P_{2}$, which corresponds to the forces of gravity.

For the zero position we take the rest position of the car system. The potential energy of the system is found as the work performed by the elastic force $F$ of the spring and the forces of gravity $P_{1}, P_{2}$ and $P_{3}$ during the transition of the system from the position under consideration (Fig. $1, b$ ) to zero (Fig. 1, $a$ ).

For the force of elasticity:

$$
P_{1}=c \cdot \lambda_{2},
$$

where $c$-spring stiffness; $\lambda$ - elongation (compression) of the spring.

For gravity:

$$
P_{2}=-P_{3} S_{3}=-m_{3} g S_{3},
$$

where $S_{3}$ represents the offset of the loading platform.

For the entire automotive system (Fig. 2, b), the full potential energy of the working process of this system can be represented by the formula:

$$
P=P_{1}+P_{2}=c \lambda_{2}-m_{3} g S_{3} .
$$

We propose to express the quantities $\lambda$ and $S_{3}$ through the angle $\varphi$.

Determine the amount of elongation (compression) of the spring $\lambda$, taking into account that in the position of static equilibrium the spring may have some static (initial) elongation or compression $\lambda_{c m}$, which is necessary to maintain equilibrium (in our case to balance the force of gravity $P_{3}$ acting on the load 3).

When turning the wheel $l$ at an angle $\varphi$, the spring receives an additional to $\lambda_{c m}$ elongation $S_{A}=R_{1} \varphi$. Therefore, $\lambda=\lambda_{c m}+\mathrm{S}_{A}=\lambda_{c m}+R_{1} \varphi$. Express $S_{3}$ through $\varphi, S_{3}=R_{1} \varphi$.

Substituting all the values found in equation (2), we obtain:

$$
P=c\left(\lambda_{c m}+R_{1} \dot{\varphi}\right)^{2}-m_{3} g R_{1} \dot{\varphi} .
$$


Let us define the generalized force $Q_{\varphi}$ :

$$
Q_{\varphi}=-\frac{\partial P}{\partial_{\varphi}}=-c R_{1}\left(\lambda_{c m}+R_{1} \dot{\varphi}\right)+m_{3} g R_{1} .
$$

The value of $\lambda_{c m}$ is found from the conditions at equilibrium, ie when $\varphi=0$, there must be $Q_{\varphi}=0$. Assuming in (4) $\varphi=0$ and $Q_{\varphi}=0$, we obtain $c R_{1} \lambda_{c m}=m_{3} g R_{1}$, where:

$$
\lambda_{c m}=\frac{m_{3} g}{c},
$$

Substituting in (4) the value, $\lambda_{c m}$, we obtain the formula of generalized force:

$$
Q_{\varphi}=-c R_{1}^{2} \varphi .
$$

The kinetic energy $T$ of the automotive system will be defined as the sum of the kinetic energies $T_{1}$ of the process weight per wheel $l$ and $T_{2}$ of the process weight per wheel 2 and the kinetic energy $T_{3}$ of the loading platform, i.e.:

$$
T=T_{1}+T_{2}+T_{3} .
$$

Since the wheels 1 and 2 rotate around the axes, and the loading platform 3 moves gradually, the above kinetic energies are determined by the formulas:

$$
\mathrm{T}_{1}=\frac{I_{0} \omega_{1}^{2}}{2} ; \quad T_{2}=\frac{I_{0} \omega_{2}^{2}}{2} ; \quad T_{3}=\frac{m_{3} V_{3}^{2}}{2},
$$

where $I_{0}$ - moment of inertia of technological weight; $\omega$ is the speed of rotation of the wheels; $V$ is the speed of movement of the technological platform, where $I_{01}$ and $I_{02}$ wheels are defined:

$$
I_{01}=\frac{m_{1} R_{1}^{2}}{2} ; \quad I_{02}=\frac{m_{2} R_{2}^{2}}{2},
$$

where $m_{1}$ and $m_{2}$ - weight taken on wheels 1 and 2 .

The velocities $\omega$ and $\mathrm{v}$, which are included in equation (14), are expressed in terms of the generalized velocity $\varphi$. Then: $\omega_{1}=\varphi$ and $V_{3}=\varphi R_{1}$. The speed $V_{B}$ of the point $B$ in contact with the wheel $R_{3}$, $V_{B}=\omega_{3} R_{3}$, whence: $\omega_{3}=\frac{\dot{\varphi} R_{3}}{R_{2}} ; V_{B}=\omega_{1}\left(R_{1}+R_{2}\right)=\dot{\varphi} R_{3}$.

Substituting the values of $I_{01}, I_{02}, \omega_{1}, \omega_{2}, V_{3}$ in equation (14), and then in equation (13), we obtain a formula for calculating the kinetic energy when performing the workflow of the energy-modular layout of the vehicle:

$$
\begin{gathered}
T=\frac{m_{1} R_{1}^{2}}{2} \frac{1}{2} \dot{\varphi}^{2}+\frac{m_{2} R_{2}^{2}}{2} \frac{1}{2} \frac{\dot{\varphi}^{2} R_{1}^{2}}{r_{2}^{2}}+\frac{m_{3} \dot{\varphi} R_{3}^{2}}{2}=a_{0} \dot{\varphi}^{2} \\
a_{0}=\left(m_{1}+2 m_{2}+0.25 m_{3}\right) .
\end{gathered}
$$

\section{Research results}

Result of the calculations according to the formula:

$$
Q=-c R^{2} \varphi
$$

the Excel environment dependences were received:

$$
\begin{aligned}
& Q=f(R, \varphi) ; \\
& T=f\left(T, a_{0}\right) .
\end{aligned}
$$


Based on the results of the calculation graphical dependences are constructed: dependence of the generalized force on the radius of the wheel and the angle of its rotation (tunnel effect of the energy modular layout of the vehicle) (Fig. 14); the working area (kinetic energy) of the energy modular layout of the vehicle (Fig. 15).

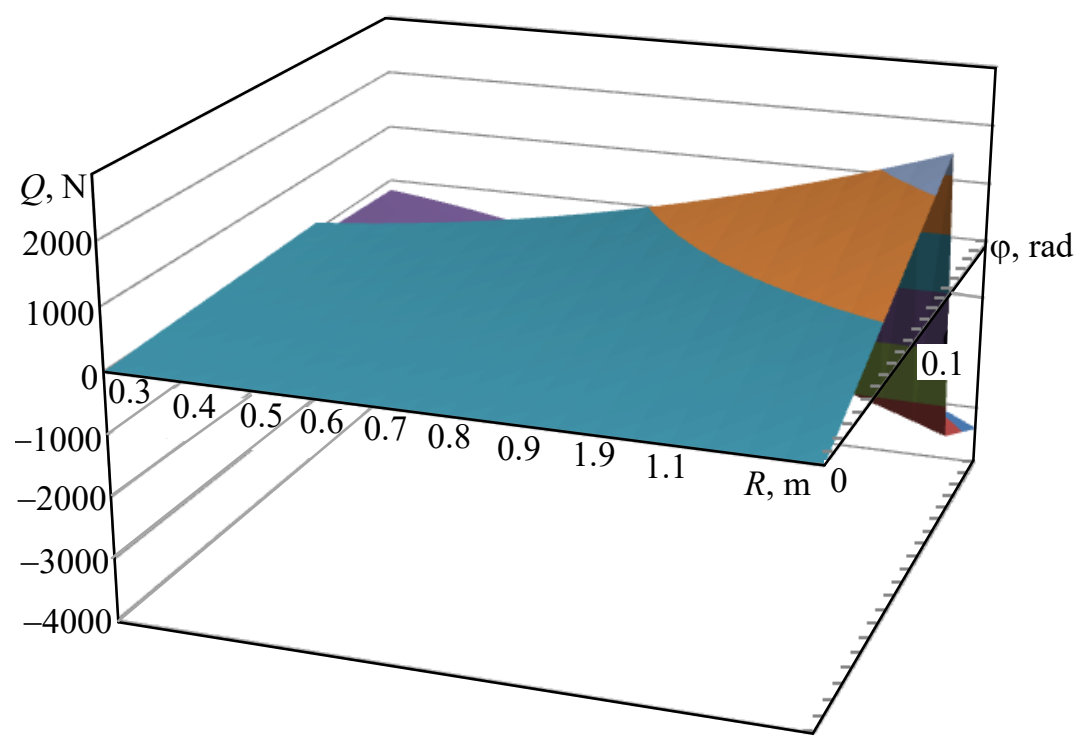

$$
\begin{aligned}
& Q, \mathrm{~N} \\
& 2000 \ldots 3000 \\
& \square 1000 \ldots 2000 \\
& \square \ldots 1000 \\
& \square-1000 \ldots 0 \\
& --2000 \ldots-1000 \\
& \square-3000 \ldots-2000 \\
& \square-4000 \ldots-3000
\end{aligned}
$$

Fig. 14. Dependence of the generalized force on the radius of the wheel and the angle of its rotation (tunnel effect of the movement of the energomodular layout of the vehicle)

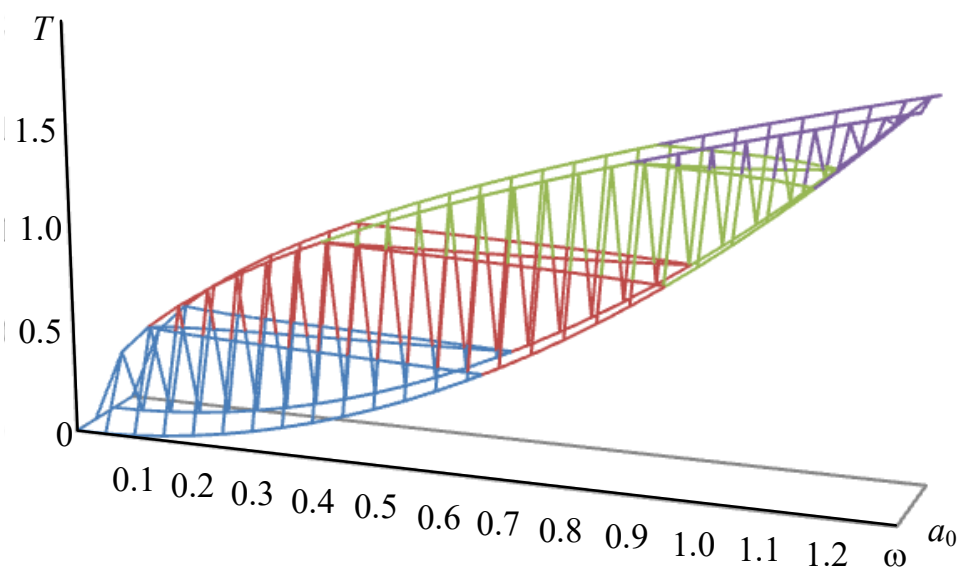

$\square 1.5 \ldots 2.0$

$\square 1.0 \ldots 1.5$

$\square 0.5 \ldots 1.0$

$\square 0.0 \ldots .0 .5$

Fig. 15. Working area (kinetic energy) of the energomodular layout of the vehicle

\section{From the above we can draw conclusions:}

1. Based on the analysis of the patent and technical literature, theoretical research was developed energy-modular layout of the automotive system.

2. Theoretical researches of energy-modular layout of automobile system are carried out.

3. On the basis of the conducted theoretical researches in the EXEL environment calculations and the constructions which are directed on visualization of operating modes of power-modular layout of automobile system are constructed.

4. According to the schedule of operation of the energy-modular layout of the car system, it is established that the developed energy-module layout of the car system works according to the "TONE EFFECT" mode. 


\section{Література}

1. Кнюх А.Б., Козлов М.А., Михайлов Е.П. Создание универсальных устройств безопасности-один из возможных путей совершенствования грузоподъёмных машин. Журнал Подъёмные сооружения. Специальная техника. 2011. № 5, С. 24.

2. Шевченко С.І., Полупан С.В. Аналіз впливу механічної характеристики приводу при гальмуванні на динамічні навантаження. Вісник східноукраӥнського національного університету імені Володимира Даля. 2019. № 2, (250). С. 125-130.

3. Козлов М.А. Михайлов Е.П., Кнюх А.Б. К вопросу определения оптимального угла наклона неприводных роликовых конвейеров. Журнал Подъёмные сооружения. Специальная техника..2011, № 5, C. 25-26.

4. Козлов М.А., Михайлов Е.П., Кнюх А.Б. О К.П.Д. блоков при различных схемах их использования для подъёма грузив. Журнал Подъёмные сооружения. Специальная техника. 2013. № 6. C. $14-15$.

5. Козлов М.А., Дащенко А.Ф., Николаева И.А. Динамика движения груза, прикладываемого с некоторой скоростью к концу упругого заторможенного стержня. Журнал Подъёмнье сооружения. Специальная техника.2013. № 10. С. 18-20.

6. Козлов М.А., Дащенко А.Ф., Николаева И.А. Как сотрудничество «Январки» и Одесского политеха помогало растить кадры для производства и создавать новые машины. Журнал Подъёмные сооружения. Специальная техника. 2014. № 1-2. С. 17-18.

7. Козлов М.А., Дащенко А.Ф., Николаева И.А. О некоторых проблемах механизма передвижения кранов на рельсовом ходу. Журнал Подъёмные сооружения. Специальная техника. 2016. № 1. C. $8-11$.

8. Козлов М.А., Дащенко А.Ф., Николаева И.А. Безопасная полиспастная подвеска лифтовых кабин. Журнал Подъёмные сооружения. Специильная техника. 2016. № 1. С. 26.

9. Козлов М.А., Дащенко А.Ф. Николаева И.А. Возможный вариант определения силовых факторов при изгибе каната на Блоках. Журнал Подъёмные сооружения. Специиальная техника. 2017. № 4. C. 21-22.

10. Петров Л.М., Кішянус І.В., Скоріченко О.І. Проект автомобіля з додатковим реактивним поштовхом у зоні плями контакту колісного рушія 3 опорною поверхнею : монографія. Рига : Baltija Publishing. 2019. С. 229-246.

11. Козлов М.А., Дащенко А.Ф. Николаева И.А. О некоторых специфических проблемах безопасности и надёжности работы грузоподъёмных машиню. Журнал Подъёмные сооружения. Специальная техника. 2017. № 8. С. 16-19.

12. Петров Л.М., Осєнчинін М.Г. Проект автомобільної системи із силовим збудженням коливань у технологічній платформі : монографія. Рига : Baltija Publishing. 2020. 524 c.

\section{References}

1. Knukh, A.B., Kozlov, M.A., \& Mikhailov, E.P. (2011). Creation of universal safety devices is one of the possible ways to improve hoisting machines. Lifting equipment and Special devices Magazine, 5, 24.

2. Shevchenko, S., \& Polupan, E. (2019). Analysis of the influence of the mechanical characteristics of the drive during braking on dynamic loads. Visnik of the Ukrainian National University for the Name of Volodymyr Dahl, 2, 250, 125-130.

3. Kozlov, M.A., Mikhailov, E.P., \& Knukh, A.B. (2011). On the question of determining the optimal angle of inclination of non-driven roller conveyors. Lifting equipment and Special devices Magazine, 5, 25-26.

4. Kozlov, M.A., Mikhailov, E.P., \& Knukh, A.B. (2013). About K.P.D. blocks for various schemes of their use for lifting loads. Lifting equipment and Special devices Magazine, 6, 14-15.

5. Kozlov, M.A., Dashchenko, A.F., \& Nikolaeva, I.A. (2013). Dynamics of the movement of a load applied at a certain speed to the end of an elastic braked rod. Lifting equipment and Special devices Magazine, 10, 18-20.

6. Kozlov, M.A., Dashchenko, A.F., \& Nikolaeva, I.A. (2014). How the cooperation of "Yanvarka" and the Odessa Polytechnic helped to raise personnel for production and create new machines. Lifting equipment and Special devices Magazine, 1-2, 17-18.

7. Kozlov, M.A., Dashchenko, A.F., \& Nikolaeva, I.A. (2016). On some problems of the mechanism of movement of cranes on a rail track. Lifting equipment and Special devices Magazine, 1, 8-11.

8. Kozlov, M.A., Dashchenko, A.F., \& Nikolaeva, I.A. (2016). Safe Reeving Suspension of Elevator Cabins. Lifting equipment and Special devices Magazine, 1, 26. 
9. Kozlov, M.A., Dashchenko, A.F., \& Nikolaeva, I.A. (2017). Possible variant of determining the force factors during bending of the rope on the Zh blocks. Lifting equipment and Special devices Magazine, 4, 21-22.

10. Petrov, L.M., Kishyanus, I.V., \& Skorichenko, O.I. (2019). The project of the car with additional reactive shipment at the zones of the contact of the wheel rush with the support surface. Collective monograph, Riga: Baltija Publishing, p. 229-246.

11. Kozlov, M.A., Dashchenko, A.F., \& Nikolaeva I.A. (2017). On some specific issues of safety and reliability of hoisting machines. Lifting equipment and Special devices Magazine, 2017, No. 8, p.16-19.

12. Petrov, L.M., \& Osunchinin, M.G. (2020). The project of an automobile system from the power to raise the problem at the technological platform. Collective monograph. Riga: Baltija Publishing, p. 336-351.

Петров Леонід Миколайович; Petrov Leonid, ORCID: https://orcid.org/0000-0001-5709-9986

Борисенко Тарас Миколайович; Borisenko Taras, ORCID: https://orcid.org/0000-0002-0557-7322

Кішянус Ігор Володимирович; Kishianus Igor, ORCID: https://orcid.org/0000-0001-7838-5607

Петрик Юрій Миколайович; Petryk Yuriy, ORCID: https://orcid.org/0000-0003-4589-4282

Received January 12, 2021

Accepted March 18, 2021 